\title{
DESAIN APLIKASI MEDIA PEMBELAJARAN UNTUK MEMBANTU PEMAHAMAN SISWA TENTANG KONSEP GEOMETRI
}

\author{
Utin Desy Susiaty ${ }^{1}$, Dwi Oktaviana ${ }^{2}$ \\ Prodi Pendidikan Matematika, IKIP PGRI Pontianak ${ }^{1,2}$ \\ Email: d3or4f4ty4@gmail.com¹,dwi.oktaviana7@gmail.com²
}

\begin{abstract}
Abstrak
Penelitian ini bertujuan untuk mengetahui rancangan media komputer berbasis Adobe Flash CS5 pada materi konsep segiempat dan seberapa jauh media ini dapat membantu pemahaman konsep segi empat. Jenis penelitian yang dilakukan adalah penelitian pengembangan. Tahapan penelitian ini meliputi analisis kebutuhan, penyusunan media komputer, uji coba terbatas produk dan terakhir evaluasi produk. Analisis data yang dilakukan untuk angket evaluasi komponen media adalah analisis data kuantitatif, sedangkan angket evaluasi materi media dan hasil belajar siswa yaitu pre test dan post test menggunakan analisis data kualitatif. Pemanfaatan media ini mampu membantu siswa dalam peningkatan pemahaman konsep sebesar $42,969 \%$ dan tetap menjawab dengan jawaban yang tepat sebesar 26,563\%. Hasil angket evaluasi media terhadap media yang dikembangkan tergolong baik dengan rata-rata 33,75 dari skor maksimal 38. Hal ini menunjukkan bahwa media ini baik digunakan untuk membantu pembelajaran konsep segiempat di kelas.
\end{abstract}

Kata kunci: Adobe Flash CS5, Konsep Segiempat, Media Pembelajaran

\begin{abstract}
The purpose of this research is to find out the design of an Adobe Flash CS5-based computer media on the quadrilateral concept material and how far this medium can facilitate understanding of the quadrilateral concept. It is a development research with stages consisting of needs analysis, computer media compilation, limited product trial and product evaluation. Data analysis performed for questionnaire of medium component evaluation is quantitative data analysis, while for questionnaire of medium material evaluation and student's learning results, which are pre-test and post-test, is qualitative data analysis. The use of the medium can help students to improve their concept understanding of $42.969 \%$ and to keep answering with the right answer of $26.563 \%$. The result of medium evaluation questionnaire on media being developed is good with average score of 33.75 from maximum score of 38. This shows that the media is useful to facilitate the quadrilateral concept learning in a classroom.
\end{abstract}

Keywords: Adobe Flash CS5, Quadrilateral Concept, Learning Medium

\section{PENDAHULUAN}

Kegiatan pembelajaran yang berpusat pada peserta didik diharapkan dapat meningkatkan peranan peserta didik yang lebih aktif, kreatif, dan terampil, baik dalam memahami konsep matematika atau memecahkan masalah dalam pembelajaran. Student centered (pembelajaran terpusat pada peserta didik) adalah pembelajaran yang dilakukan peserta didik secara mandiri, dan guru sebagai fasilitator [1]. Proses pembelajaran yang berpusat pada peserta didik tidak boleh hanya tertuju pada nilai yang memuaskan saja, tetapi bagaimana proses mendapatkan nilai yang memuaskan selama pelaksanaan pembelajaran. Untuk mendapatkan nilai yang baik maka guru perlu menciptakan suasana pembelajaran yang dapat meningkatkan motivasi dan minat belajar peserta didik, sehingga pemahaman peserta didik terhadap materi menjadi lebih baik.

Matematika merupakan salah satu mata pelajaran yang sulit dan menyebabkan siswa mengalami kesulitan untuk memahami materi pelajaran matematika yang abstrak. Pelajaran matematika merupakan salah satu mata pelajaran yang memiliki manfaat besar dalam kehidupan 
[2]. Matematika memberikan kesempatan kepada siswa untuk melatih mental mereka dan akan berpengaruh terhadap perkembangan intelektual mereka. Melalui pelajaran matematika siswa akan mampu belajar untuk memperoleh pengetahuan secara sistematis. Kesulitan siswa mempelajari matematika juga disebabkan oleh sifatnya yang abstrak dan membutuhkan kemampuan berpikir logis serta terurut [3]. Jadi, tidak salah jika sebagian besar siswa tidak cukup tertarik dan yakin mampu mempelajari matematika dengan baik. Bila anak belajar matematika terpisah dari pengalaman mereka seharihari maka anak akan cepat lupa dan tidak dapat mengaplikasikan matematika [4].

Penggunaan teknologi dalam pengajaran makin hari makin berkembang. Perkembangan teknologi dan komunikasi membawa dampak besar bagi kehidupan, salah satunya dalam bidang pendidikan. "Sebagai cara untuk menjembatani kesulitan-kesulitan pengajaran khususnya matematika yang memiliki sifat abstrak dalam materi segiempat, multimedia dapat menjadi sarana yang menunjang, yaitu sebagai simulasi" [5]. Pada proses pembelajaran saat ini, multimedia mulai banyak digunakan sebagai media pembelajaran untuk membantu guru menyampaikan materi yang ingin disampaikan. Fasilitas penggunaan media di berbagai sekolah sebagai penunjang kegiatan belajar mengajarpun sudah semakin lengkap. Hampir setiap mata pelajaran menggunakan multimedia sebagai media pembantu atau penunjang dalam proses pembelajaran. Penjelasan yang harus didukung dengan simulasi akan sangat mudah menggunakan multimedia karena tidak perlu menghadirkan langsung benda atau keadaan nyatanya.

Menurut hasil wawancara dengan salah satu guru matematika di SMP Koperasi Pontianak mengatakan bahwa banyak siswa yang tidak mengetahui hierarki dari bangun-bangun segiempat, kemudian ketersediaan media yang kurang memadai sehinga waktu yang digunakan untuk menjelaskan hierarki dari bangun segiempat terlalu lama. Selain hasil wawancara dengan guru peneliti juga melakukan wawancara mengenai sejauh mana pengetahuan mengenai hierarki segiempat kepada siswa dan kemudian didapat hasil bahwa banyak siswa yang kurang paham dengan konsep dan sifatsifat segiempat. Untuk membantu merepresentasikan masalah di atas, peneliti bermaksud membuat media pembelajaran berbasis multimedia dengan menggunakan aplikasi Adobe Flash CS5. Peneliti menggunakan aplikasi ini karena dapat merepresentasikan sesuatu dalam bentuk visual tanpa harus membawa alat peraga dan mengeluarkan biaya yang banyak. Dengan adanya media berbasis komputer ini, peneliti berharap dapat memberi wawasan baru mengenai konsep dan sifatsifat bangun datar segiempat.

Sebelumnya, beberapa penelitian yang menjadi acuan bagi peneliti yang pertama adalah tentang Pengembangan Bahan Ajar Program Linear Menggunakan Aplikasi Geogebra Berbantuan Android. Hasil penelitian menunjukkan: (1) telah dihasilkan bahan ajar berbasis Android pada pokok bahasan program linear dengan penilaian dari beberapa ahli yaitu: (a) ahli materi memberikan penilaian baik $(68,18 \%)$; (b) ahli media memberikan penilaian baik $(65 \%)$; (c) guru mata pelajaran memberikan nilai sangat baik $(86,84 \%)$; (2) implementasi media pembelajaran terhadap siswa mendapatkan respon baik dengan skor $78,4 \%$ masuk dalam kategori baik serta penilaian minat belajar belajar siswa mendapat penilaian 80\% masuk dalam kategori baik; (3) bhaan ajar yang dikembangkan dapat meningkatkan minat belajar siswa pada pokok bahasan linear terutama materi 
geometri, kalkulus dan aljabar dengan didukung penilaian angket minat siswa memperoleh persentase $80 \%$ termasuk dalam kategori baik [6].

Selain itu, tentang Pengembangan Media Pembelajaran Interaktif Adobe Flash Cs5 dan Infokus terhadap Pemahaman Konsep Matematis. Temuan penelitian tersebut menyatakan bahwa hasil penelitian ini berupa media pembelajaran interaktif Adobe Flash CS5 untuk meningkatkan pemahaman siswa kelas VII di SMP PGRI 11 Palembang [7]. Kualitas media pembelajaran ini ditentukan oleh: (1) aspek kelayakan isi materi berdasarkan penilaian dari ahli materi oleh dosen Matematika dengan skor rata-rata 3,6 pada tahap I dan 4,1 pada tahap II, serta penilaian dari guru matematika dengan skor rata-rata 5 untuk aspek ketetapan konsep dan kompetensi dan 4,8 untuk aspek kualitas keterampilan dengan kategori sangat valid, (2) penilaian ahli media memperoleh skor rata-rata 3,1 dengan kategori cukup valid dan 3,9 dengan kategori sangat valid, (3) respon siswa terhadap aspek pembelajaran menunjukkan skor rata-rata 4,1 , aspek materi 4,0, dan aspek media 4,1. Ketiga skor tersebut menunjukkan kategori sangat baik. Hasil pre-test dan post-test mendapatkan skor rata-rata 82,94. Perolehan skor post-test meningkat 14,23 $(82,94: 97,17)$ serta perolehan gain score 0,85 dengan kategori tinggi. Berdasarkan hasil tersebut menunjukkan bahwa media pembelajaran Adobe Flash CS5 layak digunakan dalam pembelajaran konsep matematis di siswa kelas VII.

\section{METODE}

Penelitian ini termasuk jenis penelitian dan pengembangan pendidikan (Educational Research and Development, yang disingkat R\&D). Jenis penelitian R\&D adalah suatu proses yang digunakan untuk mengembangkan dan memvalidasi produkproduk pendidikan [8]. Secara umum penelitian dilakukan dalam tiga tahapan, yaitu (1) Studi Pendahuluan, Perancangan Draft Program, dan (3) Pengembangan Program.

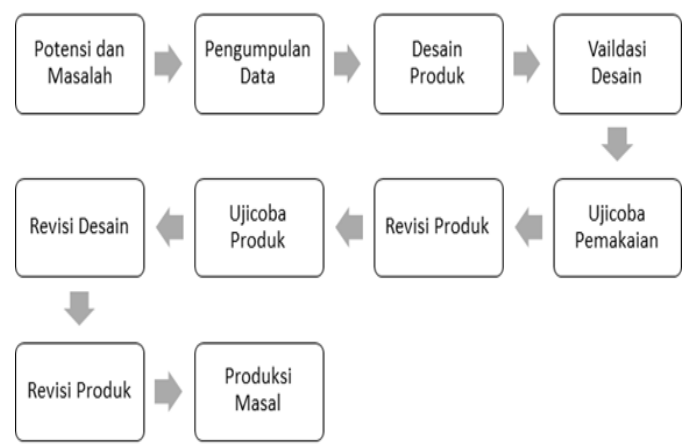

\section{Diagram 1. Model Prosedural Pengembangan Media Menurut [8]}

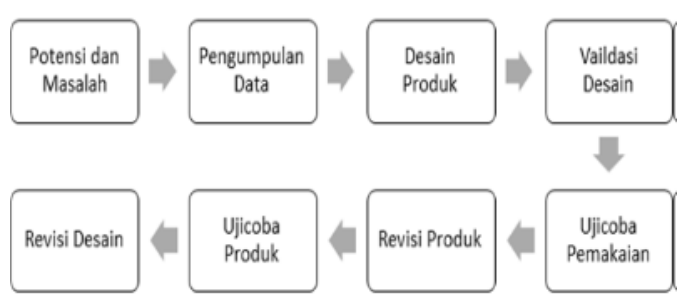

Diagram 2. Model Prosedural Pengembangan Media oleh peneliti

Dalam hal ini, peneliti menggunakan enam langkah prosedural, bedanya dengan langkah prosedural yang dilakukan oleh [9], peneliti hanya melakukan sekali putaran dalam memvalidasi media. Berikut penjelasan langkah prosedural yang peneliti lakukan: (1) melakukan analisis kebutuhan: analisis dilakukan dengan cara mewawancarai guru dan memberikan pretest kepada para siswa untuk mengetahui seberapa jauh pengetahuan konsep segiempat; (2) penyusunan media untuk perencanaan awal: perencanaan awal dalam penyusunan media ini akan divalidasi oleh pakar media; (3) uji coba kepada guru: setelah media divalidasi oleh para ahli, media akan diuji coba kepada guru terlebih dahulu. Uji coba ini dilakukan dengan tujuan untuk mengetahui apakah media yang dikembangkan sudah sesuai dengan tujuan khusus dan mengumpulkan informasi yang dapat dipakai untuk meningkatkan media sebagai 
keperluan perbaikan; (4) penyusunan media komputer untuk revisi media: revisi media yang dikerjakan berdasarkan hasil validitas oleh para ahli dan uji coba kepada guru; (5) uji coba kepada siswa: setelah proses revisi media dan dirasa media yang dibuat sudah sesuai dengan tujuan khusus maka langkah selanjutnya adalah uji coba kepada siswa; (6) evaluasi produk: data yang diperoleh berasal dari hasil post-test dan penyebaran angket untuk siswa mengenai kelayakan media yang dibuat. Setelah data diperoleh kemudian data dianalisis sebagai evaluasi media. Subjek utama dalam penelitian ini adalah siswa-siswi kelas VII A. Objek dari penelitian ini adalah pengembangan media komputer berbasis Adobe Flash CS5 yang telah dibuat dapat membantu siswa memahami konsep matematika khususnya materi segiempat. Penelitian dilaksanakan di salah satu sekolah di Pontianak, Kalimantan Barat. Terdapat tiga macam data yang akan diambil, antara lain: (1) informasi mengenai sejauh mana pemahaman konsep siswa mengenai segiempat; (2) hasil pre-test dan post-test berupa uraian mengenai konsep segiempat; (3) informasi mengenai kekurangan media komputer yang dibuat untuk memperbaiki pemahaman konsep segiempat.

\begin{tabular}{|c|c|c|c|c|c|c|c|c|c|}
\hline HAS & $\begin{array}{l}D \\
\text { b }\end{array}$ & & & & & & & & \\
\hline Siswa & & $\mathrm{mo}$ & Itel & $\mathrm{nA}$ & spe & $\mathrm{Pe}$ & ilai & & Jumlah \\
\hline & 1 & 2 & 3 & 4 & 5 & 6 & 7 & 8 & Skor \\
\hline 1 & 4 & 4 & 4 & 4 & 3 & 3 & 3 & 3 & 27 \\
\hline 2 & 4 & 4 & 4 & 4 & 4 & 4 & 4 & 4 & 32 \\
\hline 3 & 4 & 5 & 5 & 5 & 4 & 5 & 5 & 5 & 38 \\
\hline 4 & 5 & 5 & 4 & 5 & 5 & 4 & 4 & 5 & 37 \\
\hline 5 & 4 & 4 & 4 & 4 & 3 & 3 & 4 & 5 & 31 \\
\hline 6 & 5 & 5 & 5 & 3 & 4 & 5 & 5 & 5 & 37 \\
\hline 7 & 5 & 5 & 5 & 4 & 4 & 5 & 5 & 5 & 38 \\
\hline 8 & 4 & 4 & 4 & 4 & 3 & 4 & 4 & 3 & 30 \\
\hline Total & & & & & & & & & 270 \\
\hline
\end{tabular}

Analisis Data Angket evaluasi komponen media

Berdasarkan data angket evaluasi komponen media yang diperoleh, didapat nilai $\mathrm{A}=38, \mathrm{~B}=27$. Selanjutnya dapatkan nilai $\mathrm{C}=2,2 \approx 2$. Dengan demikian dapatlah ditentukan kualifikasi penilaian siswa terhadap media yaitu sebagai berikut:

Tabel 2. Ketentuan Kualifikasi Penilaian

Siswa terhadap Media

\begin{tabular}{cc}
\hline Skor & $\begin{array}{c}\text { Kualifikasi } \\
\text { Penilaian }\end{array}$ \\
\hline $27 \leq \mathrm{x}<29$ & Sangat Kurang \\
$29 \leq \mathrm{x}<31$ & Kurang \\
$31 \leq \mathrm{x}<33$ & Cukup \\
$33 \leq \mathrm{x}<35$ & Baik \\
$35 \leq \mathrm{x}<38$ & Sangat Baik \\
\hline
\end{tabular}

Dengan melihat pada ketentuan kualifikasi penilaian siswa terhadap media di atas maka diperoleh penilaian masing-masing siswa sebagai berikut:

\begin{tabular}{|ccc|} 
Tabel 3. Kualifikasi Penilain Siswa & \multicolumn{2}{c}{$\begin{array}{c}\text { Terhadap } \\
\text { tedia }\end{array}$} \\
\hline Siswa & Skor & Kualifikasi \\
\hline 1 & 27 & Sangat Kurang \\
2 & 32 & Cukup \\
3 & 38 & Sangat Baik \\
4 & 37 & Sangat Baik \\
5 & 31 & Cukup \\
6 & 37 & Sangat Baik \\
7 & 38 & Sangat Baik \\
8 & 30 & Kurang \\
$\Sigma$ Skor & 270 & Baik \\
Rata-Rata & 33,75 & \\
\hline
\end{tabular}

Selanjutnya berdasarkan kualifikasi penilaian siswa terhadap media yang dibuat pada tabel di atas, maka dapat ditentukan presentase untuk masingmasing kualifikasi. Berikut ini adalah presentase untuk masing-masing kualifikasi penilaian siswa.

\section{Kualitas Produk Multimedia Pembelajaran Interaktif}

"The purpose for conducting design experiments was not limited to developing explanatory constructs, but could also include developing, testing, and revising sequences of instructional activities" [10]. Dapat diartikan bahwa tujuan dari sebuah desain penelitian tidak hanya untuk membangun sebuah konstruk yang jelas, tetapi juga mencakup pengembangan, 
pengujian, dan memperbaiki aktivitas pengajaran.

\begin{tabular}{ccc}
\multicolumn{3}{c}{ Tabel 4. Presentase Kualifikasi } \\
Penilaian Media \\
\hline \multicolumn{3}{c}{$\begin{array}{c}\text { Jumlah } \\
\text { siswa }\end{array}$} \\
Kualifikasi \\
penilaian & & \\
\hline Sangat kurang & 1 & $12,5 \%$ \\
kurang & 1 & $12,5 \%$ \\
Cukup & 2 & $25 \%$ \\
Sangat baik & 4 & $50 \%$ \\
Total & 8 & $100 \%$ \\
\hline
\end{tabular}

Melihat tabel presentase kualifikasi penilaian media di atas yaitu tabel 4 . Peneliti mengambil kesimpulan bahwa sebagian besar mengatakan bahwa media yang telah dibuat sangat baik untuk digunakan oleh siswa, yaitu sebanyak 4 orang siswa atau sebesar $50 \%$. Sebanyak 2 siswa atau $25 \%$ siswa yang menilai cukup, 1 siswa atau $12,5 \%$ menilai kurang dan 1 siswa atau $12,5 \%$ siswa yang menilai sangat kurang. Selanjutnya secara rata-rata berdasarkan hasil perhitungan pada tabel 4 , penilaian siswa terhadap media yang telah dibuat adalah baik dengan skor rata-rata 33,75. Dengan demikian dapat dikatakan bahwa penilain yang diberikan siswa terhadap media komputer berbasis Adobe Flash CS5 untuk membantu pemahaman konsep segiempat yang telah dibuat peneliti ini adalah baik.

\section{Analisis Data Angket Evaluasi Materi Media}

Berdasarkan data mengenai angket evaluasi materi media pembelajaran menggunakan media komputer berbasis Adobe Flash CS5 ini dapat dilihat bahwa siswa tertarik dengan berbagai alasan yang diberikan. Siswa merasa tidak bosan karena disajikan dengan video atau animasi yang menarik walaupun ada beberapa yang merasa bahwa terdapat beberapa kalimat atau kata yang digunakan masih sulit dipahami namun tidak menurunkan rasa ingin tahu siswa. Kesesuaian animasi dan gambar dengan materi yang telah dipelajari dinilai siswa sudah sesuai, walaupun hampir seluruh siswa tidak menjelaskan secara rinci dimana letak kesesuaiannya. Hampir seluruh siswa memberikan tanggapan yang sama yaitu sesuai dengan materi pembelajaran konsep segiempat. Media ini juga dinilai membantu siswa dalam memahami konsep segiempat dengan berbagai alasan. Siswa menjadi lebih jelas dan mudah memahami konsep segiempat, tidak membuat bosan, lebih menarik untuk belajar konsep segiempat dan menambah pengetahuan baru bagi mereka. Selama uji coba siswa menilai tidak mendapati kekurangan pada media dan kendala dalam pengoprasiannya. Siswa merasa mudah memahami dan mengerti isi media, walaupun ada beberapa siswa yang harus dilakukan penekanan materi saat menjelaskan definisi.

\section{Analisis Data Hasil Belajar Siswa}

Berikut ini akan ditunjukkan banyaknya siswa yang mengalami perubahan peningkatan maupun penurunan pemahaman konsep sebelum uji coba dan setelah uji coba menurut sub materi.

Tabel 5. Presentase Dampak Penggunaan Media pada Setiap Sub Materi

\begin{tabular}{ccccc}
\hline Sub materi & Peningkatan & Penurunan & Tetap tepat & Tetap kurang tepat \\
\hline Trapesium & $21,875 \%$ & $15,625 \%$ & $53,125 \%$ & $9,375 \%$ \\
Layang layang & $56,25 \%$ & $0 \%$ & 12,55 & $31,25 \%$ \\
Jajar Genjang & $71,875 \%$ & $6,25 \%$ & $3,125 \%$ & $18,75 \%$ \\
Persegi Panjang & $18,75 \%$ & $18,75 \%$ & $31,25 \%$ & $31,25 \%$ \\
Belah Ketupat & $43,75 \%$ & $0 \%$ & $12,5 \%$ & $43,75 \%$ \\
Persegi & $37,5 \%$ & $6,25 \%$ & $43,75 \%$ & $12,5 \%$ \\
\hline
\end{tabular}


Tabel 6. Dampak Penggunaan Media Keseluruhan Materi

\begin{tabular}{ccccc}
\hline & Peningkatan & Penurunan & Tetap tepat & Tetap kurang tepat \\
\hline Jumlah & 55 & 11 & 34 & 28 \\
Presentase & $42,96875 \%$ & $8,59375 \%$ & $26,5625 \%$ & $21,875 \%$ \\
\hline
\end{tabular}

\section{Implementasi Media}

Pada pembuatan media ini type lembar kerja yang digunakan adalah ActionScript 3.0 karna dapat menggunakan fungsifungsi yang lebih mudah dibandingkan ActionScript 2.0. Setelah itu, mulai mendesain iconpack dari background sampai dengan tombolnya agar tampilan terlihat menarik dan seragam. Tomboltombol yang telah dibuat diberikan animasi agar semakin menarik. Setelah seluruh gambar dan animasi icon pack selesai dibuat dan disimpan pada library langkah selanjutnya adalah menyusun media pembelajaran yang setiap tampilan halamannya dibuat pada kotak frame.

Hasil analisis wawancara sebagai pedoman untuk mencari kebutuhan yang diperlukan mengatakan bahwa perlu adanya media pembelajaran segiempat yang dapat mempersingkat waktu dan tenaga sehingga peneliti memilih media komputer. Hal ini juga didasari dengan fasilitas sekolah yang memadai dengan adanya LCD di setiap kelas dan laboratorium komputer. Banyaknya jawaban siswa yang tidak bervariasi dan hanya memilih bentuk umum suatu bentuk khusus segiempat, misalnya bentuk jajar genjang, juga menjadi alasan peneliti untuk membuat media komputer dengan animasi yang dapat menunjukkan keterkaitan bangun segiempat yang satu dengan yang lainnya sehingga diharapkan siswa dapat mengidentifikasi bangun segiempat dengan lebih bervariasi dan tepat. Terdapat dua proses pembelajaran yang dirancang dalam pengembangan media ini. Proses yang pertama siswa perlu mengikuti proses pembelajaran secara continue yang dipandu oleh fasilitator. Proses pertama ini dipakai sebagai langkah awal pengenalan materi segiempat, karena pengenalan materi akan ditampilkan secara runtut dari pengenalan bangun segiempat dengan permainan drag and drop, kemudian dilanjutkan dengan pengelompokkan bangun segiempat dengan permaianan drag anddrop juga, selanjutnya penjelasan segiempat dengan bentuk khusus menggunakan animasi yang dapat secara acak dipilih sub materi mana yang ingin dipelajari terlebih dahulu kemudian ditutup dengan penjelasan diagram keluarga segiempat sebagai kesimpulan dari materi segiempat. Proses yang kedua siswa dipandu oleh fasilitator dapat secara acak memilih sub materi dan permainan yang ada di proses pertama sesuai dengan kebutuhan pembelajaran. Dari hasil uji coba media yang diikuti oleh 36 siswa, diketahui bahwa dengan pemanfaatan media komputer berbasis Adobe Flash CS5 ini siswa terbantu dalam memahami sub materi segiempat dengan perubahan pemahaman konsep yang meningkat yaitu jajar genjang sebesar $71,875 \%$, layanglayang sebesar 56,25\%, belah ketupat sebesar 43,75\%, persegi sebesar 37,5\%, trapesium sebesar $21,875 \%$ dan persegi panjang sebesar 18,75\%. Pemanfaatan media ini juga tidak banyak mengubah pemahaman konsep beberapa siswa yang sudah menjawab dengan benar yaitu pada sub materi trapesium sebesar 53,125\%, persegi sebesar $43,75 \%$, persegi panjang sebesar 31,25\%, layang-layang dan belah ketupat sebesar $12,5 \%$ dan jajar genjang sebesar 3,125\%. Kedua dampak positif ini didukung oleh hasil angket evaluasi materi media yang mengatakan bahwa selama uji coba penggunaan media ini mereka tidak merasa bosan karena adanya animasi 
gambar kemudian animasi atau gambar yang ditampilkan sesuai dengan materi yang dipelajari, dirasa adanya pengetahuan baru yang siswa dapatkan, dan selama penggunaan media ini siswa tidak terganggu dengan pengoperasiannya yang tidak terlalu rumit.

Selain berdampak positif di atas, ada beberapa siswa yang mengalami penurunan pemahaman konsep yaitu pada sub materi persegi panjang sebesar $18,75 \%$, trapesium sebesar $15,625 \%$, jajar genjang dan persegi sebesar $6,25 \%$. Selain itu juga ada beberapa siswa yang tetap mejawab tidak tepat yaitu pada sub materi belah ketupat sebesar $43,75 \%$, persegi panjang dan layang-layang sebesar $31,25 \%$. Hal ini dikarenakan terdapat beberapa kalimat di media yang masih sulit untuk dipahami siswa sehingga perlu adanya penekanan berulang-ulang yang dilakukan oleh fasilitator. Presentase dampak penggunaan media untuk seluruh sub materi yang menunjukkan bahwa dampak terbesar yaitu siswa mengalami peningkatan pemahaman konsep sebesar 42,969\%, kemudian tetap menjawab dengan tepat sebesar $26,563 \%$, tetap menjawab dengan tidak tepat sebesar $21,875 \%$ dan mengalami penurunan pemahaman konsep sebesar 8,592\%.

Terdapat beberapa penelitian yang relevan dengan penelitian ini. Di antaranya penelitian dengan judul $A$ Design and Development of E-Learning Content for Multimedia Technology Using Multimedia Game. Hasil dari penelitian ini adalah "multimedia technology after playing game are higher than before, statistically significant at the 0.05 level, indicating that e-learning content based on multimedia, multimedia technology subject can be enhanced students knowledge based on the assumption" [11]. Penelitian dengan judul Selection Sorting Algorithm Visualization Using Flash. Hasil penelitian ini menunjukkan bahwa "Student understand easily the concept of selection sort by looking at the visualization. Learning material text is more affective if it is provided with graphic, animation, or video to be learned by student"'[12]. Berdasarkan penelitian tersebut dapat disimpulkan bahwa multimedia berbasis Adobe Flash dapat menciptakan pembelajaran yang menyenangkan, memotivasi, meningkatkan antusias siswa dalam belajar, serta meningkatkan daya ingat siswa.

\section{SIMPULAN}

Menurut analisis kebutuhan diperlukan media pembelajaran yang dapat membantu guru dalam mempersingkat waktu dan tenaga, kemudian melihat hasil jawaban siswa saat membedakan suatu bentuk khusus segiempat dengan menjawab gambar hanya pada umumnya. Berdasarkan pada analisis kebutuhan tersebut dipilihlah pengembangan media komputer berbasis Adobe Flash CS5 untuk membantu konsep segiempat dengan penambahan animasi pada penjelasan untuk menampilkan keterkaitan bangunbangun segiempat dan permaianan drag and drop sebagai langkah awal pengenalan materi segiempat. Terdapat dua proses pembelajaran yang dapat dilakukan, yang pertama proses pembelajaran dilakukan secara runtut yang kedua proses pembelajaran yang dapat dilakukan secara acak sesuai kebutuhan.

Pemanfaatan media yang telah dikembangkan peneliti memiliki dampak yang positif yaitu peningkatan pemahaman konsep pada sub materi jajar genjang, layang-layang, belah ketupat, persegi, trapesium dan persegi panjang. Hal ini didukung oleh hasil angket evaluasi materi media yang mengatakan bahwa selama uji coba penggunaan media ini mereka tidak merasa bosan karena adanya animasi gambar, kemudian animasi atau gambar yang ditampilkan sesuai dengan materi 
yang dipelajari, dirasa adanya pengetahuan baru yang siswa dapatkan, dan selama penggunaan media ini siswa tidak terganggu dengan pengoperasiannya yang tidak terlalu rumit. Selain itu, ada beberapa siswa yang mengalami penurunan pemahaman konsep yaitu pada sub materi persegi panjang, trapesium, jajar genjang dan persegi. Kemudian ada pula beberapa siswa yang tetap menjawab dengan tidak tepat yaitu pada sub materi belah ketupat, persegi panjang dan layang-layang sebesar. Hal ini didukung oleh hasil angket evaluasi materi media yang mengatakan bahwa terdapat beberapa kalimat di media ini yang masih sulit untuk dipahami siswa sehinga perlu adanya penekanan berulangulang yang dilakukan oleh fasilitator.

\section{UCAPAN TERIMA KASIH}

Peneliti banyak menerima bantuan dalam melaksanakan dan menyelesaikan penelitian ini. Oleh karena itu, pada kesempatan ini peneliti mengucapkan terima kasih kepada semua pihak Kemenristekdikti yang telah membantu dana serta IKIP-PGRI Pontianak dan Lembaga Penelitian dan Pengabdian pada Masyarakat atas pengelolaan administrasi yang baik bagi proyek penelitian ini. Pihak SMP Koperasi Pontianak yang banyak membantu sehingga penelitian dapat dilaksanakan. Pihak Kemenristekdikti yang telah banyak membantu dalam hal bantuan dana untuk memperlancar penelitian ini.

\section{DAFTAR PUSTAKA}

[1] J. Froyd, \& N. Simpson. "StudentCentered Learning Addressing Faculty Questions about Student Centered Learning". Couse, Curriculum, Labor, and Improvement Conference Washington DC, vol. 30, no. 11, 2010.

[2] E. Ayda, \& D. Widjajanti. Pengembangan Perangkat
Pembelajaran Teorema Pythagoras dengan Media Berbantuan Komputer. Jurnal Riset Pendidikan Matematika, vol. 1, no. 2, pp. 216226, 2014.

[3] D. A. Sousa, D. A. How the brain learns mathematics. Thousand Oaks, CA: Corwin Press, 2008.

[4] M. Van den Heuvel-Panhuizen. Mathematics education in the Netherlands: A Guide Tour. CDRom of the RME Materials, produced for the ICME9 Congress in Japan, July, 2000.

[5] Munir. Pembelajaran Jarak Jauh Berbasis Teknologi Informasi dan Komunikasi. Bandung: Alfabeta, 2009.

[6] I. Fazar, Zulkardi, dan Somakim. Pengembangan Bahan Ajar Program Linear Menggunakan Aplikasi Geogebra Berbasis Android. Jurnal Pendidikan Dan Pembelajaran Matematika, vol 9, no 1, pp. 6-11, 2006.

[7] Destiniar. Pengaruh Media Pembelajaran Adobe Flash Player dan Infokus terhadap Pemahaman Konsep Matematis. Jurnal Pendidikan dan Pembelajaran Matematika, vol 9, no 2, pp. 277282, 2006.

[8] M. D. Gall, J. P. Gall, dan W. R Borg. Educational Research an Introduction. 7 th Edtion. Boston: Pearson Education, 2003.

[9] Borg and M. D. Gall. Educational Research: An Introduction. Longman Inc: New York.

[10] A. Sfard, K. Gravemeijer, \& E. Yackel. Symbolizing and Instructtional Design-Developing Instructional Sequen-Ces to Support Students Mathematical Learning. A Journey in Mathematics Education Research, pp. 76-82. New York: Springer, 2011. 
[11] T. Kaewkiriya. A Design and Development of E-Learning Content for Multimedia Technology Using Multimedia Game. International Journal of Software Engineering \& Applications, vol. 4, no. 6, pp. 61-69, 2013.

[12] H. Sutopo. Selection Sorting Algorithm Visualization Using Flash. The International Journal of Multimedia \& Its Applications, vol. 3, no. 1, pp. 22-35, 2011. 